\title{
Total Mobilisation from Below: Abeyance Networks, Threats and Emotions in Hong Kong's Freedom Summer
}

\author{
Edmund W. Cheng \& Samson Yuen
}

\begin{abstract}
This paper examines the origins and dynamics of an extraordinary wave of protests in Hong Kong in 2019 and 2020. Despite lacking visible political opportunities and organisational resources, the movement drew prolonged, mass participation unparalleled in the city's history and much of the world. Drawing on onsite and online data, we conceptualise Hong Kong's Freedom Summer as a form of total mobilisation from below. The totality of mobilisation depended on a set of permissive and productive conditions: abeyant civil society networks concealed after the Umbrella Movement activated by fear over extradition to an authoritarian regime and anger towards unregulated police action. The movement's characteristics are further examined in regard to protest scale, mobilisation structure, alternative space, and group solidarity. The spasmodic moments of mobilisation are thus explained by the nexus of network building in an unreceptive political environment and participatory experience in conjunctural events.
\end{abstract}

Keywords: contentious politics, movement continuity, anti-extradition movement, threats, emotions, China, Hong Kong

\section{Introduction}

Since 9 June 2019, Hong Kong has experienced by far the most intensive and resilient wave of mass protests in its modern and contemporary history. ${ }^{1}$ Triggered by a proposed extradition bill that would have transferred suspects in the city to mainland China, millions of Hong Kong citizens took to the street in what evolved into the city's broadest expression of dissent. The movement objectives quickly swelled from withdrawing the bill and investigating police brutality to shielding civil liberties and installing democratic institutions. As the aim of upholding the integrity of the liberal enclave and counter-public sphere at China's periphery informed and sustained mass participation throughout the summer, ${ }^{2}$ we call the movement Hong Kong's Freedom Summer.

The sudden eruption of unprecedented mobilisation caught many observers by surprise, including the Beijing and Hong Kong authorities, the democratic opposition, foreign politicians, journalists, academics, and participants. Few saw it coming, as the political environment was utterly favourable to the regime and adverse to civil society. After the Umbrella Movement in 2014, the democratic opposition's repeated efforts to organise resistance to controversial bills and policies ended in vain. In parallel, the Hong Kong Special Administrative Region Government, under the rule of a career civil servant, was restoring its legitimacy through performance. Even fewer observers expected the movement to maintain its momentum in the face of increased state repression. However, what seems to be a textbook example of a leaderless movement, exceeding the wildest expectations of the most quixotic prognosticators, drew people from all walks of life to perform acts of defiance. The movement synchronised

\footnotetext{
${ }^{1}$ The Canton-Hong Kong Strike lasted longer, but it was a top-down initiative of a smaller scale. The protest against the extradition bill began with a sit-in on 15 March and a rally on 31 March, but the march on 9 June set off a chain of actions and reactions.

${ }^{2}$ Lee and Sing 2019.
} 
peaceful rally and radical gambit, coordinated diasporic activism and city-wide crowdfunding, and translated into the opposition's landslide electoral victory, unionization and political consumption.

According to two university polls, 36.4 and 42.2 percent of the city's seven million inhabitants participated in the movement in August 2019 and May 2020, respectively. ${ }^{3}$ This stunning scale and duration of collective actions surpassed those of other movements worldwide, including the anti-war and leftist protests in Europe and America in the 1960s; the third and fourth waves of democratisation in East Asia, South America, and Inner Asia in the 1980s and 2000s; and the anti-austerity and prefigurative protests that occurred worldwide in the 2010s, which typically mobilised 3 to 25 percent of the local population. ${ }^{4}$

What accounts for this level of mobilisation despite the lack of visible political opportunities and organisational resources? How did the movement sustain mobilisation for a year and across sectors? To what extent has the mass mobilisation revealed and transformed the ethos of the citizens and the ways they see and practise politics?

This paper seeks to explain how and why Hong Kong's total mobilisation from below became possible. We first examine how civil society networks concealed in preceding periods permitted the initial petitions and shaped citizens' perceptions of the threats towards their existing liberties. The evolution from movement abeyance to contentious events in Hong Kong is surveyed to avoid what E.P. Thompson calls "a spasmodic view of popular history" ${ }^{5} \mathrm{We}$ then analyse the characteristics of total mobilisation from below under which the scale, structure, space and solidarity of the contentious action mutated in unprecedented ways. This novel example of networked movement that swept the globe in 2019 is analysed to trace its dynamics and ramifications.

The scope of our analysis begins in the post-2014 period, when grassroots, sectoral and digital activism replaced street protests, providing the basis for the formidable emergence and outburst during summer 2019, and ends in January 2020, when the coronavirus pandemic halted mass mobilisation.

\section{Movement Abeyance, Threats, and Emotions}

The mainstream literature dealing with the emergence and development of social movements finds little resonance in the Hong Kong protests. Resource mobilisation theory infers that structural conditions matter. Resources, defined as any social, political, or economic capacity, regulate the emergence of social movements. ${ }^{6}$ Organisational strength is seen as essential in overcoming collective action problems. The professionalisation of protests is inevitable for movement organisations to articulate grievances, devise strategies, and generate an increasing return to mass participation. ${ }^{7}$ The political opportunity structure model contends against but also refines resource mobilisation theory by accounting for the timing of and rationality in contentious politics. Increased regime openness, visible elite disunity, available policy channels, and dwindling repressive capacity are common signals of widening political opportunities. These opportunities foster social actors' cognitive understanding of the political system as vulnerable, thereby igniting their collective actions. ${ }^{8}$

\footnotetext{
${ }^{3}$ CCPOS, random opinion polls, $\mathrm{N}=842$ and $\mathrm{N}=5149$, August 2019 and May 2020.

${ }^{4}$ Ancelovici et al. 2016, 91-92; Lanchovichina 2017, 122.

5 Thompson 1971, 76.

${ }^{6}$ Jenkins 1983.

${ }^{7}$ McAdam 1982.

${ }^{8}$ Tarrow 2011 [1994].
} 
However, political opportunities were blocked, and movement organisations were impeded in Hong Kong before summer 2019. In the post-Umbrella period, the central and local authorities formed a united front, endorsing a nationalist discourse and an attrition strategy that concurrently co-opted the elite and quelled dissent. ${ }^{9}$ Moderate pro-regime politicians were replaced by dependent subordinates, and the available policy channels for institutional deliberation were closed. Hence, although a handful of social and business elites expressed grave concerns over the extradition bill in April 2019, they were summoned by Beijing officials in May 2019 and required to unconditionally support the Hong Kong government. Nevertheless, the authorities' attrition strategy at that time remained restrained by the rule of law, which afforded space for civil society networks to endure.

Moreover, the opposition's organisational resources and institutional platforms were strikingly weakened. Although the pro-democracy camp secured two more seats in the 2016 Legislative Council (Legco) elections, the disqualifications of elected legislators in late 2016 followed by the imprisonment of leading activists in mid-2017 generated a strong sense of despair. ${ }^{10}$ The rise of localism created an ideological rift within the opposition camp, preventing veteran political parties from recruiting young and prominent activists. ${ }^{11}$ Polling data registered a continued decline in citizens' level of efficacy over time. ${ }^{12}$ Most importantly, the majority of protestors did not take to the street to support the appeals made by the opposition leaders, nor did they foresee a reasonable chance of success. ${ }^{13}$ Their cognitive process and cause of action were therefore at odds with structural-rationalist assumptions.

Charles Tilly and Jack Goldstone concede that threats can be more crucial than opportunities in mobilising contentious action. ${ }^{14}$ Threats are potent, denoting the "probability that existing benefits will be taken away or new harms inflicted if challenging groups [fail] to act collectively". ${ }^{15}$ Threats often induce contention in hybrid and authoritarian regimes, where the responsive political institutions and elite disunity commonly present in democracies are unavailable. ${ }^{16}$ Studies of contentious events in China and Taiwan affirm that grievances are often better articulated and mobilisation better organised under a sense of threat. ${ }^{17}$ Research on Hong Kong's protests has proposed notions such as "rearguard politics", "civil society in selfdefence", "citizen self-mobilisation", "bottom-up activism", and "constructive identity against blind nationalism" to explain spontaneous yet sizeable participation. ${ }^{18}$ However, these studies tend to regard China's authoritarian encroachment as a backdrop and unearth the organisational and communicative aspects of mass mobilisation. How threats are perceived among the crowd and related to conjunctural events, including regime responses and protest narratives, remains unclear. ${ }^{19}$

The cultural turn in contentious politics, however, offers an alternative lens through which to mediate the structural-rationalist approach. The cultural approach suggests that emotion not only is a formative condition of social movements but also serves a constitutive role in shaping movement characteristics and dynamics. ${ }^{20}$ This approach has prompted some scholars to investigate the interactions between contentious events and abeyant moments,

\footnotetext{
${ }^{9}$ Yuen and Cheng 2017; Guo, 2019; Yuen and Leung 2020.

${ }^{10}$ Cheng 2020.

${ }^{11} \mathrm{Ku} 2019$.

${ }^{12}$ See World Values Survey Waves 6 to 7 and Asian Barometers Surveys Waves 4 to 5 .

${ }^{13}$ Lee et al. 2019.

${ }^{14}$ Goldstone and Tilly, 2001.

${ }^{15}$ Almeida 2003, 347.

${ }^{16}$ Almeida 2003.

${ }^{17}$ Cai 2008; Ho 2015.

${ }^{18}$ Lui 2003; Ma 2005; Lee and Chan 2010; Cheng 2016; Veg 2017; Ho 2019; Ortmann 2020.

${ }^{19}$ Goodwin et al. 2001.

${ }^{20}$ Jasper 1997; Hank and Klandermans 2013.
} 
focusing on how collective identities constitute movement trajectories. ${ }^{21}$ Movement abeyance, defined as a period where contention is latent, is thus not a vacuum. Without enacting overt challenges, activists continue to preserve their values, identity and vision through deliberation and advocacy to the broader community. ${ }^{22}$ Various studies in American, European and Middle Eastern countries have affirmed that "movement half-way houses", "activist subcultures" or "non-movements" can cultivate the social capital of atomised individuals to prepare for future mobilisation. ${ }^{23}$

\section{The Conditions and Characteristics of Total Mobilisation from Below}

While mobilisation is a core concept in contentious politics, notions such as social mobilisation, political contention, and popular struggle are used interchangeably. Charles Tilly defines mobilisation as "the process by which a group goes from being a passive collection of individuals to an active participant in public life". ${ }^{24}$ Robert Jansen adds a class dimension by defining popular mobilisation as "the mobilisation of ordinarily marginalised social sectors into publicly visible and contentious political action". ${ }^{25}$ Joe Foweraker adds a temporal aspect, defining popular struggle as a trajectory that transforms a specific agenda into one based on general interests. ${ }^{26}$ In contrast, the idea of total mobilisation is associated with a top-down initiative organised by the state during wartime or a mega-project. Referring to its hierarchical structure, Ernst Jünger defines total mobilisation as "the channelling and management of the entire force of the nation, the people, or the proletarians of the world, into a process of production and self-production driven by the highest possible level of technological and managerial order". ${ }^{27}$

Based on the above reading, we try to conceptualise total mobilisation from below as an effort of the masses to perform acts of defiance collectively, voluntarily and persistently in the face of a crumbling socio-political order. Total mobilisation from below is often not a calculated move but a sum of actions and reactions to conjunctural events imposed on people. Conjunctural events are spontaneous occurrences over a short period of time that rupture the existing equilibrium and incite uncertainty in a large segment of society. ${ }^{28}$ Subject to these uncertainties, a decentralized protest structure is surprisingly effective for articulating threats, framing emotions, and recruiting resources over a short period. ${ }^{29}$ Unlike a revolution that aims to systematically overthrow the current political order and install a seemingly superior one, total mobilisation from below is conditioned by the regime ceiling and movement trajectory under which its protagonists aim to restore or reform the current system. Whereas both represent extraordinary moments of rapid and radical transformation of the attitudes and behaviours of the masses, their protagonists differ in the ways they see state power, boundaries of contention and the expected outcomes of their struggles. ${ }^{30}$

Total mobilisation from below depends on a combination of permissive and productive conditions. ${ }^{31}$ Permissive conditions are necessary conditions that loosen constraints on agency

\footnotetext{
${ }^{21}$ Daphi and Zamponi 2019; Fominaya 2020.

${ }^{22}$ Taylor 1989.

${ }^{23}$ Morris 1986; Sawyers and Meyer 1999; Bayat 2009.

24 Tilly 1978, 69.

${ }^{25}$ Jansen 2011, 82.

${ }^{26}$ Foweraker 2002.

${ }^{27}$ Cited from Costea and Amiridis 2017.

${ }^{28}$ Cheng and Chan 2017, 223.

${ }^{29}$ Breaugh 2013; Kadivar 2018.

${ }^{30}$ Della Porta 2014; Bayat 2017.

${ }^{31}$ Soifer 2012, 1572.
} 
or increase the causal power of contingency in a specific temporal frame. Productive conditions occur within the context of these permissive conditions to produce momentum and diffusion. In post-Occupy Hong Kong, civil society networks concealed but also preserved civic identities and liberal values are permissive conditions that permitted public deliberation and initial mobilisation. Veteran activists, community networks, and professional groups acted as the forerunners to challenge the content and procedures of the extradition bill and rally public support. The mobilisation, however, would not have become unparalleled in scale and duration without the productive conditions that expedited the participants' cognitive liberation. The fears over extradition to authoritarian China, the anger towards unregulated police action, and the construction of collective identities set in motion a bandwagon effect that sustained collective and continuous mobilisations. Opportunities were explored, resources gathered, and frames aligned at exceptional speed and with singular unity to restore the integrity of the onceliberal enclave. Once the norms and behaviours constituting one as a "comrade" were established, they informed individual and group obligations.

The totality of the mobilisation is defined by four characteristics related to the protest scale, mobilisation structure, alternative space and group solidarity that modifies the diversity and temporality of collective action: 1) the enaction of a massive scale of mobilisation to stimulate participatory experiences, including among individuals who would not otherwise participate in protests; 2) the facilitation of a leaderful protest structure to endorse a diversified repertoire, allowing groups with different skills to take turns at the helm; 3) the spilling over of the space of contention into sectoral, community and diasporic mobilisations to explore new opportunities and resources; and 4) the fostering of affective bonds to maintain group solidarity and sustain the struggle.

\section{Data and Methods}

To examine and understand the total mobilisation of the masses, this paper relies on a variety of data sources. First, we analysed the signatories of the territory-wide petitions in May 2019, which revealed the initial mobilisation. Second, we conducted a total of 27 onsite surveys between 9 June 2019 and 1 January 2020, covering every major protest and obtaining the motivations, dispositions, tactics, emotions and demographics of more than 13,000 protest participants. Third, we drew on computational network analysis of 20 million comments from the Reddit-like LIHKG forum, the main mobilisation platform, between 1 April 2019 and 31 January 2020. The topic analysis will reveal how digital communication allowed protesters to construct frames and cultivate identities in the absence of centralised leadership. Finally, we collected testimonies from several organisers and volunteers of professional and community groups to elucidate the role of abeyance networks during different stages of mobilisation.

\section{Networks and Practices during Movement Abeyance}

Despite the absence of territory-wide mobilisation, the post-2014 period saw the rise of grassroots groups, sectoral initiatives and digitally enabled connective actions that aimed to preserve and perpetuate the ideal unattained in the 79-day occupation. ${ }^{32}$ In contrast to previous activism in Hong Kong, these abeyance networks emphasised connecting politics to everyday life, networking with atomised individuals, re-evaluating past movements, and broadening citizens' democratic imaginations. ${ }^{33}$ These post-Umbrella groups and platforms used "hidden

\footnotetext{
${ }^{32}$ Lee and Chan 2018; Ma and Cheng 2019; Pang 2020.

${ }^{33}$ Chung 2019.
} 
transcripts" to disseminate their understanding of liberties and citizenship subtly and developed a loose "network of networks" through grassroots penetration and digital communication. ${ }^{34}$

Many of these groups were informal and covert. Their informality refers to their lack of hierarchical structure and official membership. Trust was based upon personal, social, or professional ties, whereas actions were coordinated through WhatsApp groups or Facebook pages. The groups' covertness allowed them to observe the boundary between advocacy and mobilisation while at times being critical and vocal.

At least 60 grassroots community groups formed after the Umbrella Movement. A typical example was a community network named Sai Wan Changing. Between 2016 and 2018, the group organised hundreds of festive events, public screenings, bookcrossing boxes, information boards, and a community school at the west end of Hong Kong Island. These events often featured books, films, and songs that were heavily censored on major commercial outlets. These micro and spatial practices sought to redefine the connective function of urban spaces and to deepen the meaning of democratic life. By May 2020, the group had 83,000 members on Facebook.

Co-founded by veteran activists, Fixing Hong Kong was a representative grassroots network composed of not only educated youth but also blue-collar workers and ethnic minorities, many of whom were not traditional supporters of the pro-democracy camp. They met almost every evening to provide free in-house repair services in redevelopment neighbourhoods in To Ka-wan. The hidden agenda of this face-to-face interaction was to help residents realise how their poverty and displacement were situated in the political context. Between 2015 and 2018, the activists engaged in more than 2000 visits. Their innovative model helped to expand their volunteer team and attracted many established NGOs to seek collaboration. One of its founders explained how the group built up strong ties and participatory experiences at the grassroots level:

\footnotetext{
We want to make politics matter in everyday encounters. We do not restrict ourselves to repairing goods and offering welfare. What we aim to haul is each other's souls, through hard work. And we have deepened the ties with those we encountered. Our clients invite us to their festive events, and we bring them back to attend forums. ${ }^{35}$
}

In parallel, more than 20 professional groups for doctors, lawyers, social workers, and accountants were formed before and after the Umbrella Movement. ${ }^{36}$ They largely shared the conviction that many traditional associations or trade unions in their sectors were either too conservative or bound by administrative red tape. A smaller and informal group of people sharing similar views can be more flexible and open.

A group of social workers focused on outreach formed the Reclaiming Social Work Movement. Aiming to inject progressive politics into social issues, these social workers focused on fieldwork and education. The group has approximately 30 core members in its WhatsApp group willing to work on issues related to electoral politics and social empowerment. The group, despite being small in size, raised dissenting voices among the professional organisations, pushing them to acknowledge the need for reform. During the early months of the protests, the group remained set on pushing forward the agenda to support teenage protesters, which was soon absorbed by the newly formed alliance among themselves, the professional organisations, and frontline social workers.

Another notable group, the Progressive Lawyers Group, adopted a more proactive and down-to-earth approach than the bar association and the law society would sanction. Whenever

\footnotetext{
${ }^{34}$ Scott 1990; Castells 2015.

${ }^{35}$ Interview with activist, Hong Kong, 11 November 2018.

${ }^{36} \mathrm{Ma}, 2020$.
} 
there were controversial legal cases or issues, they produced an easy-to-understand version of the relevant legal concepts and prosecution procedures. They also began networking with volunteer lawyers to bail out arrested activists and protesters in 2015. In summer 2019, they reached more than 120 members working in the legal profession and gave more than 300 interviews to share their legal analysis with local and foreign presses. A convenor of the group articulated how managing differences built up solidarity in the informal group:

\begin{abstract}
We believe that our legal expertise can serve society better. While some colleagues stress advocacy, others contest boundaries. We value these differences, as they are deliberative. Regardless or our rank and politics, we have been more committed. We make ourselves available for countless bails, trials, commentaries and interviews. ${ }^{37}$
\end{abstract}

The grassroots and sectoral networks further evolved through digital communication. A series of digital and social media platforms continued to allow activists and groups to connect with their potential supporters while lowering the cost of communication and content distribution. ${ }^{38}$. Through digital means, activists exercised freedom of speech and provided the narrative and space for the consumption and construction of the "counter publics". ${ }^{39}$ When the political environment was non-receptive to mass protest, these digitally-enabled connective actions continued to connect political actors, aggregate resources, and preserve dissenting voices.

First, a few online media platforms emerged in what was perceived as a highly censored and subservient media landscape in the post-2014 period. Often formed by professional journalists, these platforms ensured editorial autonomy through crowdfunding or subscription. The notable examples included Stand News, Citizen News, and Fact Wire News Agency, which offered a variety of investigative reports, expert columns and activist features. These media platforms provided live broadcasts and fact-checking during the summer of 2019 and often became the primary source of movement information. Second, veteran political commentators revamped their channels on YouTube. These key opinion leaders provided instant analysis of current affairs and rallied a large number of loyal supporters. MemeHK, Singhai, and D100 were popular channels whose six digital subscriptions increased two to three times during the movement. Siu's Talk of MemeHK, for instance, made him one of the top 5 Patreon creators in the world in 2020. Third, LIHKG, a Redditt-like online forum, was established in 2016. It was a splinter of Golden Forum that had helped mobilise participation in the Umbrella Movement. Due to concerns that the original forum had been infiltrated by the Five Cents Party, the new forum adopted new precautions: a registration system using the information service provider's email to verify identity, a popularity interface that highlighted the most discussed topics and a decentralised organisation that prevented users from following each other. These features afforded a partisan yet networked virtual community that soon became the main mobilisation platform of the Freedom Summer.

During movement abeyance, the increase in state repression and the communicative efforts in network building facilitated a process of reconciliation between different prodemocracy camps. The results of the 2017 Chief Executive Electoral Committee elections illustrated the strength of these networks during movement abeyance. Through a coordinated campaign, the pro-democracy camp managed to increase its electorate from 205 in 2012 to 327 in 2017, securing more than one-fourth of the seats in most of the sectors with a sizeable individual voter base. A trend of "affective depolarization" was used to maintain solidarity once the movement erupted. ${ }^{40}$ Admittedly, these committed activists alone do not account for

\footnotetext{
${ }^{37}$ Interview with lawyer, Hong Kong, March 2019.

${ }^{38}$ Lee, Chan, and Chen 2020.

${ }^{39}$ Cheng, 2020.

${ }^{40}$ Lee 2020.
} 
the unprecedented mobilisation in 2019. Nevertheless, their latent networks aggerated as online or offline nodes to perform special functions in different stages of mobilisation.

\section{Movement Experiences and Initial Mobilisation}

On 12 February 2019, the Hong Kong government revealed its plan to amend the Fugitive Offenders Ordinance and the Mutual Legal Assistance in Criminal Matters Ordinance. These amendments would have allowed Hong Kong to surrender fugitives to jurisdictions with which it does not have existing bilateral extradition agreements, including Mainland China. Supported by the pro-regime majority in the Legco, the government asserted that the amendments would pass. The diminished opposition also made the government overconfident in its grip on civil society.

Nonetheless, protest momentum had been gradually building in every corner of society. Veteran movement organisations remained the forerunners in organising collective actions. On 15 March, Demosisto organised a sit-in at the Government Headquarters at Admiralty. Nine activists were arrested, but the bill passed. On 31 March and 28 April, the Civil Human Rights Front organised two rallies, attended by 12,000 and 130,000 participants, respectively. Side by side, democrats voiced their criticisms within the Legco and tried to stall the amendments. Between these events, activists produced a slogan to frame the movement as "anti-extradition to China", which carried a double meaning of extradition and mourning (song zhong). On 5 June, Apple Daily produced a trilogy of short films entitled "Forests and fields for animal fugitives", "On the chopping board", and "Imprisoned night". All of these developed a coherent theme that every individual would be vulnerable should the amendments pass and that the city would be forever changed. These films attracted more than 1.5 million YouTube views before the scheduled rally on 9 June, illustrating the widespread public concern. ${ }^{41}$

Moreover, a series of unplanned online petitions in May was another step towards mobilisation. The petition campaign started with the city's secondary schools and universities, as alumni, students and teachers from different schools produced their own statements. The intent was to lobby senior government officials to adopt their school mottos. Two education networks listed the institutions participating in the petition but criticised the other as a copycat and biased. The debate led more opinion leaders to share the lists. In the end, the campaign swiftly spread to different industries: lawyers, bankers, accountants, journalists, doctors, nurses and tech workers all crafted their own petitions in their words. Parents, homemakers, immigrants, churches, residential communities and different hobby groups then followed suit. Our analysis shows that 487 petitions were circulating on the Internet, and nearly 270,000 individuals signed them. This means that, on average, each petition was signed by approximately 560 people. Most initiators of these petitions did not hold any leadership positions in these networks or associations, but they counted on digital communication and social identification to mobilise atomised individuals. These stunning figures suggest that civil society networks were crucial in launching the events to come in the following months.

\section{[Table 1 about here]}

Table 1 shows the correlations between the signing of the petition in May 2019 and participation in major social protests in Hong Kong since 2012. A clear trend is that those who participated in preceding protests continued their activism by signing petitions from their schools, community associations, or professional networks. The ripple effects reach back to the Tiananmen Vigil in 1990, Anti-National Education Campaign in 2012 and the Umbrella Movement in 2014. Protest participation during one's formative years has an enduring impact

\footnotetext{
${ }^{41}$ Next Film 2019.
} 
over one's lifetime but is mediated by the nature of the protest events. While the young and student participants in the Anti-National Education Campaign tended to sign petitions through their close secondary or university networks, participants on the annual 1 July differing in both age and issues of concern signed petitions through their university and professional networks. The effect of the Umbrella Movement was particularly strong, with more than 75 percent of its participants signing various petitions through their university alma mater or industry sector. The memoires of the 4 July rally, with the vigil lasting more than three decades, was extremely significant to motivate present protest participation. ${ }^{42}$ In contrast, the influence of associational groups was not that significant, partly because they were not strong-tie networks and were not nodes in the petition campaign.

\section{Perceived Threats and Unprecedented Scale of Mobilisation}

On 9 June 2019, one million Hong Kong citizens took to the streets to protest the extradition bill. Our records indicate that at least 153 professional, community and political organisations once in abeyance joined the rally. Later that evening, the Hong Kong government issued a statement acknowledging different views in society but insisting that the second reading of the bill would resume. ${ }^{43}$ Tens of thousands of protesters, mostly young persons, occupied Harcourt Road and surrounded the Legco building on 12 June. Police and protesters clashed, and the meeting was adjourned. Later that afternoon, Chief Executive Carrie Lam labelled the protesters "rioters". This categorisation revealed the tension created by the sudden appearance of grievances in a highly unaccountable government, thereby amplifying the sense of threat felt by the public. Although the Chief Executive announced the suspension of the bill on 15 June, a 35-year-old man, Marco Leung Ling-kit, had committed suicide that morning after unfurling a banner denouncing the bill. On 16 June, the protest scale reached two million. Leung displayed a banner proposing five demands, which soon became the major claims of Hong Kong's Freedom Summer.

\section{[Table 2 about here]}

Table 2 summarises the primary concerns of the protest participants in the two massive rallies on 9 and 16 June, which, according to the organisers, were attended by 1 million and 2 million people, respectively. Our onsite surveys found that worries over the "extradition of prodemocracy activists and politicians to mainland China" and "the extradition of the general public critical of political affairs of mainland authorities", "the destruction of the rule of law in Hong Kong" and "the end of one country, two systems" were the most important concerns of the participants. More than 90 percent of the participants considered these threats to dissenting voices and civil liberties their primary concerns. Other threats to Hong Kong's financial status and Hong Kong's global connectivity formed the second tier of concern, and participants were least motivated by worries over personal safety and household wealth.

Moreover, the perceived threats continued to amplify from the 9 June rally to the 16 June rally. Typically, the larger the scale of a rally is, the higher the chances of its attracting diverse participants and hence nuanced responses. However, the survey results on 16 June suggested that fear and anxiety were widespread and consensual despite the increase in protest size. All indexes had been rising, among which, concerns over personal safety, i.e., the possibility of "extradition of you, your family or friends", increased from 56.2 to 79.9 percent. The mean data suggest that the respondents leaned towards the extremely worried end of the spectrum and that their worry increased significantly from the first to the second rally.

\footnotetext{
${ }^{42}$ Cheng and Yuen 2019.

${ }^{43}$ Hong Kong Government 2019.
} 


\section{[Figure 1 about here]}

Figure 1 shows the scale of mobilisation over time from March 2019 to May 2020, revealing how the interactions between state and society had intensified the sense of threat and emotional motivation to sustain the protest movement. The trend is that the number of protesters increased over time until the number of protests peaked. The ups and downs of mobilisation are closely associated with conjunctural events. The point of intersection was in mid-August, when several critical events occurred. On 27 July, the police began to reject protest applications. On 7 August, protesters started to vandalise property following several attacks of black-shirt civilians on the streets. Meanwhile, the police used more resolute means to disperse the crowds, from making 10 arrests per day in June and July to 50 arrests per day in August and 100 in September and October. ${ }^{44}$

What explains the changing pattern of mobilisation? One possibility is that radical tactics alienated public support for the movement. Another possibility is that state repression increased the cost of participation. While both factors shaped the trajectory of the protests, the threat factor seems to have prevailed. Subsequent polling data indicated that public disapproval of police action and conduct increased from 67.7 percent in August to 71.7 percent in September, during which more than half of respondents gave ratings of zero to the police. ${ }^{45}$ The pro-democracy camp's landslide victory in the district council elections in November is another indicator that public support for the movement remained strong. The diffusion into protests at the grassroots level in malls and in workplaces seemed to be a tactical adjustment.

In the face of the total mobilisation, the attrition strategy no longer worked. Instead, the business patronage showed signs of rifts, propaganda machines failed to popularise official framing, legal tools were insufficient to induce fear, and counter-protests were ill attended. Unless the authorities compromised, they could only resort to coercive force. As of 30 June 2020, this assertive strategy has led to the firing of 21,000 rounds of teargas, 9,216 arrests and 3,000 injuries. In contrast, no police officer has yet been disciplined or prosecuted. These sequelae generated a sense that the local administrative and legal institutions could no longer shield freedoms of assembly and regulate police behaviour.

\section{Leaderful Mobilizing Structure and Diversified Repertoire}

Contrary to the popular perception, we conceptualise the movement as leaderful instead of leaderless. ${ }^{46}$ While there was no central leadership, communicative and coordinative roles were distributed among ordinary individuals and informal groups embedded in civil society networks. ${ }^{47}$ The spontaneous motto “be water" (上善若水), which can be traced back to Laozi and Bruce Lee, illustrated the movement's leaderfulness. It authorized an innovative repertoire to overcome the problem of tactical freeze that is common in networked movements. ${ }^{48}$ Retreating from an occupied zone was no longer considered cowardly but agile and reflective. It also inspired other action protocols on social media platforms to restrain or suppress ideological differences. Identification with the civic-nonviolent camp or militant camp was left behind to ensure solidarity and allowed different groups of protesters to "take turns". As the movement continued to unfold, this leaderful structure came to terms with veteran prodemocracy movement organisations, agreeing to remove "political resignation" as one of the five protest demands and replace it with "universal suffrage", thereby turning the defensive

\footnotetext{
${ }^{44}$ Police records.

${ }^{45}$ CCPOP, September 2019.

${ }^{46}$ Cheng 2020.

${ }^{47}$ Costanza-Chock 2012; Cai 2016.

48 Ting 2020.
} 
movement into a proactive one. Recognising the lack of political accountability within the city, some protesters turned abroad to build global alliances and thereby exploit opportunities.

On 11 June 2019, a day before the protests turned violent, several Christian groups held public prayer gatherings near the government headquarters, singing Hallelujah to the Lord. Religious gatherings can be held without a permit, and these generated a peaceful framing of the protest. In the weeks that followed, mothers organised sit-ins, students besieged police stations, opposition politicians regulated police conduct at the frontline, medical participants supplied first aid to the injured, social workers treated those experiencing mental breakdowns, and lawyers set up hotlines to bail out the arrested. These diverse actions and services were implemented without prior planning or abundant resources but were instead realised through the comparative status and expertise of individuals in informal networks.

[Table 3 about here]

Table 3 shows how the leaderful structure facilitated diverse and resilient repertoires after the high tide of the movement from June to August 2019. Despite the authorities' tightening of crowd controls, one-tenth to one-third of the protesters were willing to adopt highrisk activism, such as stopping police advances and practising flash-mob actions in shopping malls or outside police stations. Nearly two-thirds of the protesters also resorted to low-risk activism, such as forming human chains outside schools and malls and posting on Lennon Walls in every district. In addition to protest actions, the protesters continued their advocacy online. They continued to sign online petitions, but the targets had changed from local governments to international bodies. Sharing pro-movement messages also became routine. To sustain their advocacy and action, the protesters also engaged in resource mobilisation: nearly half of them donated money or other materials such as goggles, helmets, masks, drinks and food coupons.

\section{[Table 4 about here]}

Political consumption is a repertoire that was proposed during the Umbrella Movement under a "yellow ribbon" identity but only materialised during the Freedom Summer. The purpose of political consumption was not merely to penalise the pro-regime businesses that were vocal in supporting the bill but also to create a self-sustained moral economy based on fair exchange and shared values and a platform for securing a livelihood for arrested protesters. More than 98 percent of the respondents participated in either buycott or boycott activities on 8 December, representing one of the most significant rises in participation among the different repertoires. Table 4 further illustrates that political consumption became a daily routine shared by young, middle-aged and elderly people. Similarly, online mobilisation remained strong among different age groups. Even though the elderly felt the impact of the digital divide, more than two-thirds of them continued to engage in online mobilisation. To minimise reported items, we did not account for class differences, but a similar pattern of support existed among different income groups.

Charles Tilly presents that repertoires of contention are not merely strategies. They are common ground shared between movement actors who finds certain tools or actions useful and then diffuse to and adopt by other groups. ${ }^{49}$ But thereafter, repertoire can also limit other options as consensus takes time to reach. William Sewell contends that the boundary of contention can be quickly and widely contested during the exceptional moments of history. Hong Kong's Freedom Summer echoes Sewell's thesis. ${ }^{50}$ In addition to the above-mentioned protest actions, scenes of violent clashes also became routine during. The newly adopted

\footnotetext{
49 Tilly 2008.

${ }^{50}$ Sewell 2005
} 
repertoire including broking into the legislature, paralysing traffic, and staging sit-ins at the airport, surprisingly, did not alien public support. ${ }^{51}$

That said, the diversified repertoires were not boundless. Despite the lack of police surveillance and the occupation of luxury malls, there was not a single report of looting throughout the entire movement. To be sure, the relative success of crowdfunding campaigns provided a continual injection of resources. The spontaneous actions of citizens leaving money on rented machines and in train stations might have also set precedent. Such collective restraint over time suggests that the movement's political claims had regulated each other's behaviours.

\section{Strategic Concern and Alternative Spaces of Contention}

Space is potent in mass mobilisation, as it "expresses conflicts between socio-political interests and forces" and "constitutes an outcome and medium of contentious politics". ${ }^{52}$ It can be an arena for the powerless to transform existing social relations and a means to make local grievances relevant to global constituencies. ${ }^{53} \mathrm{~A}$ spatial lens reveals how protesters perceive and act upon grievances and threats. Previous activism in Hong Kong featured preordained routes or occupied zones, but the Freedom Summer showed alternative spaces of contention. The extension into neighbourhoods, workplaces, and international arenas was inspired by the "be water" motto but also motivated by concern over how to rally sectors or groups that usually do not participate in rallies and exert sustained pressure on the authorities. After the storming of the Legco on July 1, public support remained high. ${ }^{54}$ However, the threats of legal prosecution and regime retribution also increased immensely. Hence, protesters urgently needed alternative arenas and means of contention. While the diffusion into different physical and virtual spaces was not a co-ordinated action, it involved strong strategic elements.

\section{[Figure 2 about here]}

Figure 2 shows that there were 528 instances of protest between March 2019 and February 2020. Since August 2019, community protests, sectoral strikes, and flash mobs clearly replaced mass rallies to sustain the movement. When the movement came to a standstill, these mobilisations offered alternative spaces and new opportunities through which to rally new constituencies. The aggregation of these grassroots, workplace and global initiatives resembled the logic of the mass rallies. On 7 July 2019, protests shifted to Salisbury Garden in Tsim Sha Tsum. This was the first time since 1989 that a mass rally had been held on the Kowloon side. The massive turnout inspired district protests in the following months. These community mobilisations connected local issues to political disenfranchisement or uncountable governance, thereby increasing proximity to their audience. Their interactions also helped activists and ordinary protesters share knowledge and coordinate tactics. Out of the 120 approved public processions during the movement, more than 70 percent were applied for by veteran politicians or activists. These individuals negotiated with the police on the protest routes, recruited a sufficient number of picketers, and were liable for any wrongdoing during the protests. This know-how explained why certain applications were approved but others were denied before the police banned all protests. However, these high-risk forerunners alone could not organise the community rallies. They were dependent on a highly decentralised but horizontally connected protest network. According to the organiser of one of the first community rallies:

\footnotetext{
${ }^{51}$ Lee et al. 2019.

${ }^{52}$ Lefebvre 1991 [1974], 365; Sewell 2001, 55.

${ }_{53}^{53}$ Martin and Miller 2003.

${ }^{54}$ Lee et al. 2019, 10.
} 
We were surprised by the others' passion. Once the community rally was approved, we recruited helpers on LIHKG and other public Telegram groups. It only took us one evening to hire 200 picketers. A few of them were from our inner circle. But the majority were strangers. We created an internal Telegram group to arrange duties and a public group to disseminate information. The public one reached 5,000 people. ${ }^{55}$

Two other organisers of district or community rallies gave similar accounts:

\begin{abstract}
We pulled manpower from the well-known Telegram platforms. Then, we contributed according to our expertise in small groups. Some of us took care of publicity; others arranged logistics. Once we decided the next moves, we circulated the details back to the main groups. Our small TG groups continued to function after the protests, with members helping other groups to apply for a protest permit, defend Lennon Walls, or organise video screenings.
\end{abstract}

Sectoral mobilisation further transformed the protest. In the past, only those with strong associational affiliations, such as teachers, lawyers and social workers, regularly protested on behalf of their sector. However, as early as July 2019, sectoral mobilisations had proliferated, with teachers, lawyers, social workers, civil servants, priests, flight attendants, accountants, transport workers, mothers, and the elderly organising sit-ins or rallies based on their occupation, trade or social identities. On 5 August, protesters initiated a city-wide general strike of workers, students and businesses. According to the Hong Kong Confederation of Trade Unions, more than 350,000 people from 50 sectors participated in the general strike, making it the largest labour action since the Canton-Hong Kong strike in 1925. Lacking any legal protection, strikes used to be difficult to organise in Hong Kong. However, participants either refused to turn up for work or called in sick. Seven major assemblies were held throughout the districts to rally those who participated.

The strike did not last long, and the two other strikes in November and January had less participation, but the democratic labour actions' potential and limitations spilled over into other arenas, allowing groups and individuals to take turns and to rally new supporters. First, many protesters blocked roads and disrupted public transit on that day. Their improvised actions aimed to prevent people from working and to give workers an excuse for missing work. Two unintended consequences of the seven district rallies were the instilling of the notion that protests should not be confined to specific physical spaces and the testing of public tolerance for radical actions. Second, the strike's short duration promoted discussion of organisational platforms and resources. This discussion in turn motivated many community organisers and professional workers to consider unionisation for democracy. ${ }^{56}$ According to the Labour Department, there were 1,712 applications for union establishment between July 2019 and March 2020, compared to just a few dozen in previous years. The yellow economic circle was activated through the idea of resisting the state-corporatist structure.

Moreover, the contentious space extended into the international realm. The first wave was kicked off by a global newspaper advertisement campaign and diasporic activism worldwide. These initiatives aimed to draw international pressure during the G20 Summit on June 26. The second wave came following rumours that the People's Liberation Army would be dispatched to quell the protests. Protesters responded to the threat with sit-ins at the airport and concurrent rallies in more than 30 cities in mid-August. In addition to framing themselves as freedom fighters on the edge of authoritarian encroachment, radical protesters constructed a discourse of "mutual destruction" (撫炒). The discourse posited that if the Chinese authorities employed extreme measures, both China and Hong Kong would suffer international sanction.

\footnotetext{
${ }^{55}$ Interview with community organiser, Hong Kong, September 2019.

${ }^{56}$ Chan 2020.
} 
Leveraging Hong Kong's financial status in the context of China's worsening economic situation and the ongoing U.S.-China rivalry, action escalation was not merely an emotional response but also a strategic calculation to force the regime to offer concession.

Atomised groups kept the movement alive by recognising the contributions of others and giving each other their unconditional trust. The alternative spaces of contention combined civil society infrastructures and digital communication networks to facilitate a division of labour that accommodated participants' varying degrees of risk tolerance, professional expertise, and social connectedness. This role distribution connected atomised individuals to their sphere of contention with comparative advantages. As a result, each participant felt a sense of ownership of the movement and helped to inject new momentum into it.

\section{Shared Emotions and Solidarity in Crisis}

Emotions are salient in protests, as they "give ideas, ideologies, identities and even interests their power to motivate". ${ }^{57}$ Anger, in particular, tends to "put fire in the belly and iron in the soul." ${ }^{58}$ However, fear or anger alone is not enough to produce collective actions and sustain mobilisation. The alignment between social cognition and collective action often occurs in a two-step process. On the one hand, the assertive police actions and associated arrests, injuries and suicides of protesters produced novel events that made the public aware of the irregularity and disorder in society. The protest participation, live broadcasts, and social media sharing of the almost daily confrontations then generated a strong sense of moral outrage among citizens. On the other hand, the decentralised protest structure was relatively effective in generating frames and protocols for the participants to interpret the situations and make sense of their participation.

On 4 September 2019, the Hong Kong government announced the withdrawal of the extradition bill. Unlike the earlier announcements of "suspension" and "the bill is dead" considered untrustworthy by the public, this was a meaningful concession. However, it came at a time when state-society confrontations had fully intensified. The 21 July Yuen Long incident, during which thugs randomly attacked civilians on public transport, created a moral shock. Other small-scale random attacks on the streets in August further popularised the notion of using militant action and vandalism to seek vengeance. As a result, the number of protestors arrested and injured reached 4,000, and seven teenagers committed political suicide, intensifying emotions to mediate threats.

Among the protest frames, “climbing mountains using your own efforts” (兄弟爬山， 各自努力) was used to justify the need for diversity in protest actions, “don't split, don't dissociate and don't snitch on anyone” (不分化、不割席、不篤灰) was used to contain and restrain the ideological differences among different protest camps, and "we go through ups and downs together, leaving no one behind” (齊上齊落, 一個都不能少) was used to produce a sense of collectiveness among different groups of protesters. These collective frames produced affective bonds between those who were once strangers but who nonetheless participated in the collective actions and shared similar identities and agendas. As such, others' suffering reinforced group solidarity and created a moral obligation to sustain one's reciprocal actions.

\section{[Table 5 about here]}

Table 5 shows the emotions across different groups of protesters at a community rally on 4 August. Anger was indeed the most common emotion across genders, generations, classes and educational backgrounds, accounting for more than 80 percent of the respondents' feelings.

\footnotetext{
57 Jasper 1997, 127.

${ }^{58}$ Gamson 1992, 32.
} 
Degree-holders had a stronger feeling of anger than their counterparts. The youth had a stronger feeling of anger, whereas senior citizens felt a lower degree of fear than their counterparts. Female participants expressed a stronger sense of fear and worry than male participants. Overall, more than 60 percent of respondents also felt worry, and only 10 percent expressed hope, but they nonetheless continued to participate. An almost identical pattern of emotion was found at a student-initiated sit-in on 16 August.

\section{[Table 6 about here]}

The respondents' anger was predominantly directed at the government or the police or both. It is, however, less clear whether respondents were worried about their own well-being, about other people suffering, or about the city's future. Table 6 suggests that their anger was triggered by police actions and that their worry was directed towards fellow protesters who were arrested or injured. An inter-group statement, "Peaceful protesters owe militant protesters", received an affirmative response from 79.5 percent of the participants. A more personalised statement, "I feel guilty when I see them being arrested", was received affirmatively by an even greater share, 91.9 percent. The sense of guilt caused many protesters to believe that they were not contributing enough to the movement. In this light, affective bonds developed among different groups of protesters to sustain their collective actions.

Another way to unpack group solidarity is to see how collective identity has unfolded. Figure 3 shows our analysis of the ranking of keywords on the LIHKG forum over time. We measured three sets of key identities, namely, the civic-nonviolent (和理非) and militant (勇武) camps, the yellow ribbon (黃絲) and yellow (黃色) affiliations, and the righteous (義士) and comrade (手足) attributes. Overall, the online protest framings were highly correlated with offline protest events. None of these terms attained prominence until the large rallies in June. Once they emerged, however, the terms civic-nonviolent and militant were widely used and closely associated. Although they were sometimes referenced to debate one another's positions and strategy, they were mostly used together to maintain the non-splitting narrative. Similarly, although yellow ribbon was widely considered a common identity of the protesters, the expression was not commonly used in the online forum. However, yellow was used widely in the later stage of the movement to refer to the yellow economic circle. Most visibly, the term “hands and legs (手足)", literally meaning brothers and sisters and conceptually denoting comrade, became the top-ranked phrase on the forum. ${ }^{59}$ The term was often associated with frontline activists and those who had been injured, allegedly disappeared, or committed suicide during the protests. These individuals were labelled "righteous", resembling crusaders, vigilantes and martyrs. These narratives indicated that the protestors were considered one group due to their common experience in the movement. That said, their solidarity was built upon moral obligations and disciplinary tropes in a time of crisis. ${ }^{60}$ It was understood that the militant protesters, who had paid a higher price, chose not to split with the moderate protesters, not vice versa. ${ }^{61}$

[Figure 3 about here]

The discursive frame authorized a series of altruistic actions, some coordinated and others spontaneous. On 30 July, online forums widely circulated the news that many students and young protesters were starving. Thousands of citizens quickly queued up in different districts to contribute the next day. One of the social workers who helped to collect and distribute coupons revealed that in less than a week, his group had received over one million worth of

\footnotetext{
${ }^{59}$ After discounting phrasal verbs such as "how" and "why" or key noun phrases of a particular week, "hands and legs" always ranked number 1 on the forum from August 2019.

${ }^{60}$ Klandermans 2002.

${ }^{61}$ Lee 2020.
} 
coupons, mostly from middle-aged citizens. ${ }^{62}$ On 23 August, hundreds of thousands of citizens formed a 50-mile human chain along three main mass transit lines to recreate the Baltic Way. The idea was put forward only four days before on LIHKG, but the citizens in Telegram chat groups and other social media platforms created maps and brainstormed routes and deployed volunteers to ensure that the chain would be uninterpreted. On 1 September, thousands of protesters who rallied at the airport were besieged by the police, who suspended all public transport. As many as 5,000 private vehicles rushed to the island to rescue those left behind. Several drivers explained that the traffic jam meant that it took three to four hours to pick up two to four passengers, but many of them went through several rounds that night. ${ }^{63}$ These varied citizen responses were diffused altruistically and performed expeditiously. Group solidarity, in this regard, mediated the participants' perception of threats following intensified repression. The shared emotions also explained why the protesters persisted in seeking justice for their comrades despite the regime's partial concession.

\section{Conclusion}

Hong Kong's Freedom Summer was an explosive and resilient mass mobilisation. Total mobilisation of this magnitude rarely occurs and is hard to predict. Observers would likely be surprised by another such unforeseen event in Hong Kong or elsewhere. This paper, however, contends that an uninterrupted view of history attending to the interplay between latent networks and conjectural events is conducive to explaining the origins and making sense of the dynamics of the total mobilisation. Without the abeyance and communicative networks that preserved civic values and identities, the participants' fears and anger alone would not have produced coordination and translated into cross-sectoral participation. The leaderful protest structure was also productive in framing the bill as a violation of those commonalities. Should the authorities have offered the concession sooner, the permissive condition of perceived threat would have been stemmed, and the disrupted power equilibrium might have been restored.

In light of these movement dynamics and narratives, we named the total mobilisation Hong Kong's Freedom Summer. Terms such as revolt and uprising were too repertoire-oriented; the majority of protesters disapproved the labels of revolution and unrest and underscored their restoration and reformist claims within the boundary of the Basic Law. Despite the presence of radical ideologies and tactics, freedom, or its erosion, drove and sustained the movement. Protesters did not deliberate what was meant by universal suffrage, the only proactive demand, arguably inferring that the primary role of democratic institutions was to protect civil liberties and the rule of law in this liberal enclave.

The total mobilisation came to a standstill when the diverse repertoires and alternative spaces of contention failed to force the regime to compromise. The spread of the pandemic, another conjunctural event, eventually halted the movement. Admittedly, Hong Kong's hybrid and subnational regime structure constrained the movement's transformative capacity. However, the movement's ripple effects were evident in the opposition's electoral victory and the unionisation efforts made within a state-corporatist context. These immediate outcomes suggest that the total mobilisation severely disrupted the static equilibrium in the hybrid regime, provoking the higher power in Beijing to revamp the political setting of the semi-autonomous city by imposing the National Security Law. A few ramifications, including the massive turnout in the opposition's primaries, the deepening of political consumption and the outcry against media censorship in the post-movement period, suggest another cycle of movement abeyance.

\footnotetext{
${ }^{62}$ Interview with social workers, Hong Kong, August 2019.

${ }^{63}$ Interview with teacher, Hong Kong, August 2019.
} 
Whether the new development constitutes a punctuated equilibrium altering Hong Kong's statesociety relations to departure from the past remains to be seen. ${ }^{64}$

\section{Reference}

Almeida, Paul D. 2003. "Opportunity organizations and threat-induced contention: protest waves in authoritarian settings." American Journal of Sociology 109(2), 345-400.

Ancelovici, Marcos, Pascale Dufour, and Héloïse Nez (eds.). 2016. Street Politics in the Age of Austerity: From the Indignados to Occupy. Amsterdam: Amsterdam University Press.

Bayat, Asefl. 2009. Life as Politics. How Ordianry People Change the Middle East. Palo Alto: Standford University Press.

Bayat, Asefl. 2017. Revolution without Revolutionaries. Making Sense of the Arab Sping. Palo Alto: Standford University Press.

Breaugh, Martin. 2013. The Plebeian Experience: A Discontinuous History of Political Freedom. New York: Columbia University Press.

Cai, Yongshun. 2008. "Power structure and regime resilience: contentious politics in China." British Journal of Political Science 38(3), 411-432.

Cai, Yongshun. 2016. The Occupy Movement In Hong Kong: Sustaining Decentralized Protest. New York: Routledge.

Castells, Manuel. 2015. Networks of Outrage and Hope: Social Movements in the Internet Age. New York: John Wiley \& Sons.

Chan, Anita. 2020. "From unorganised street protests to organising unions: the birth of a new trade union movement in Hong Kong." Made in China Journal, 15 July, https://madeinchinajournal.com/2020/07/15/from-unorganised-street-protests-to-organising-unions/. Accessed 30 July 2020.

Cheng, Edmund W. 2016. "Street politics in a hybrid regime: the diffusion of political activism in post-colonial Hong Kong." The China Quarterly 226, 383-406.

Cheng, Edmund W. 2020. "United front work and mechanisms of counter-mobilization in Hong Kong." China Journal. 83, 1-33.

Cheng, Edmund W. and Wai-yin Chan. 2017. "Explaining spontaneous occupation: Antecedents, contingencies and spaces in the Umbrella Movement." Social Movement Studies 16(2), 222-239.

Cheng, Edmund W. and Samson Yuen. 2019. "Memory in movement: collective identity and memory contestation in Hong Kong's Tiananmen vigils." Mobilization 24(4), 419-437.

Chung, Hiu Fung. 2019. "Urban Social Movement, Networking and Everyday Communicative Practice." MPhil diss., Chinese University of Hong Kong.

Costanza-Chock, Sasha. 2012. "Mic check! Media cultures and the Occupy Movement." Social Movement Studies 11(3-4), 375-385.

Costea, Bogdan and Kostas Amiridis. 2017. "Ernst Jünger, total mobilisation and the work of war." Organization 24(4), 475-490.

Daphi, Priska, and Lorenzo Zamponi. 2019. "Exploring the movement-memory nexus: Insights and ways forward." Mobilization: An International Quarterly 24(4), 399-417.

Della Porta, Donatella. Mobilizing for democracy: Comparing 1989 and 2011. OUP Oxford, 2014.

Fominaya, C. Flesher. 2020. Democracy Reloaded: Inside Spain's Political Laboratory From 15-M to Podermos. New York: Oxford University Press.

Foweraker, Joe. 2002. Popular Mobilization in Mexico. Cambridge: Cambridge University Press.

Gamson, William A. 1992. Talking Politics. Cambridge: Cambridge University Press.

\footnotetext{
${ }^{64}$ Kuran 1991.
} 
Goldstone, Jack A. and Charles Tilly. 2001. "Threat and opportunity: popular action and state response in the dynamics of contentious action.” In Ronald R. Aminzade, Jack A. Goldstone, Doug McAdam, Elizabeth J. Perry et al., Silence and Voice in the Study of Contentious Politics. Cambridge: Cambridge University Press, 179-194.

Goodwin, Jeff, James M. Jasper, and Francesca Polletta (eds.). 2001. Passionate Politics. Chicago: University of Chicago Press.

Guo, Yingjie. 2019. "From Marxism to nationalism: The Chinese Communist Party's discursive shift in the postMao era." Communist and Post-Communist Studies 52(4): 355-365.

Johnston, Hank, and Bert Klandermans (eds.). 2013. Social Movements and Culture. New York: Routledge.

Ho, Ming-sho. 2015. "Occupy congress in Taiwan: political opportunity, threat, and the Sunflower Movement." Journal of East Asian Studies 15(1), 69-97.

Ho, Ming-sho. 2019. Challenging Beijing's Mandate of Heaven: Taiwan's Sunflower Movement and Hong Kong's Umbrella Movement. Philadelphia: Temple University Press.

Hong Kong Government. 2019. "Government Responds to Procession," 9 June, https://www.news.gov.hk/eng/2019/06/20190609/20190609 231141 763.html. Accessed 31 May 2020.

Jansen, Robert S. 2011. "Populist mobilization: A new theoretical approach to populism." Sociological Theory 29(2): 75-96.

Jasper, James M. 1997. The Art of Moral Protest. Chicago: University of Chicago Press.

Jenkins, J. Craig. 1983. "Resource mobilization theory and the study of social movements." Annual Review of Sociology $9(1), 527-553$.

Kadivar, Mohammad Ali. 2018. "Mass mobilization and the durability of new democracies." American Sociological Review 83(2), 390-417.

Klandermans, Bert. 2002. "How group identification helps to overcome the dilemma of collective action." American Behavioural Scientist 45(5), 887-900.

Kong, Tsung-gan. 2020. "Hong Kong pro-democracy protests 2019-2020." Medium, 26 November, https://medium.com/@KongTsungGan/hong-kong-protests-2019-82cf32383605. Accessed 13 July 2020.

$\mathrm{Ku}$, Agnes Shuk-mei. 2019. "In search of a new political subjectivity in Hong Kong: the Umbrella Movement as a street theatre of generational change." China Journal 82(1), 111-132.

Kuran, Timur. 1991. "Now out of never: The element of surprise in the East European revolution of 1989." World Politics 44(1), 7-48.

Lanchovichina, Elena. 2017. Eruptions of Popular Anger: The Economics of the Arab Spring and its Aftermath. Washington, DC: The World Bank.

Lee, Ching Kwan, and Ming Sing (eds.). 2019. Take Back Our Future: An Eventful Sociology of the Hong Kong Umbrella Movement. New York: Cornell University Press.

Lee, Francis L. F., Michael Chan and Hsuan-Ting Chen. 2020. "Social media and protest attitudes during movement abeyance: a study of Hong Kong university students." International Journal of Communication.

Lee, Francis L. F. 2020. "Solidarity in the Anti-extradition Bill Movement in Hong Kong. Critical Asian Studies 52(1), 18-32.

Lee, Francis L. F., and Joseph M. Chan. 2010. Media, Social Mobilisation and Mass Protests in Post-Colonial Hong Kong: The Power of a Critical Event. New York: Routledge.

Lee, Francis L. F., and Joseph M. Chan. 2018. Media and Protest Logics in the Digital Era: The Umbrella Movement in Hong Kong. New York: Oxford University Press.

Lee, Francis L. F., Samson Yuen, Gary Tang, and Edmund W. Cheng. 2019. "Hong Kong's summer of uprising: from anti-extradition to anti-authoritarian protests." China Review 19(4), 1-32.

Lefebvre, Henri. 1991 [1974]. The Production of Space. Cambridge: Blackwell.

Lui, Tai-Lok. 2003. "Rearguard politics: Hong Kong’s middle class.” The Developing Economies 41(2), 161-183. 
Ma, Ngok. 2005. "Civil society in self-defence: the struggle against national security legislation in Hong Kong." Journal of Contemporary China 14(44), 465-482.

Ma, Ngok. 2020. "The plebeian moment and its traces: Post-umbrella movement professional groups in Hong Kong." In Thomas Gold and Sebastian Veg (eds.), Sunflowers and Umbrella. Berkeley: University of California East Asian Institute.

Ma, Ngok, and Edmund W. Cheng (eds.). 2019. The Umbrella Movement: Civil Resistance and Contentious Space in Hong Kong. Amsterdam: Amsterdam University Press

Martin, Deborah G. and Byron Miller. 2003. "Space and contentious politics.” Mobilization 8(2), 143-156.

McAdam, Doug. 1989. Political Process and the Development of Black Insurgency, 1930-1970. Chicago: University of Chicago Press.

Morris, Aldon D. 1986. The Origins of The Civil Rights Movement. New York: Simon And Schuster.

Next Film. 2019. "Forests and Fields for Animal Fugitives", "On the Chopping Board", and "Imprisoned Light", 5, 6 and 7 June. https://www.youtube.com/watch?v=GMPaCQUp018\&t=270s, https://www.youtube.com/watch?v=DhUFpd-qphA, https://www.youtube.com/watch?v=ZAnWB3rXN2Q\&t=9s. Accessed 31 May 2020.

Ortmann, Stephan. 2020. "Hong Kong’s constructive identity and political participation: resisting China's blind nationalism." Asian Studies Review, 1-19.

Pang, Laikwan. 2020. The Appearing Demos: Hong Kong During and After the Umbrella Movement. Ann Arbor: University of Michigan Press.

Sawyers, Traci M., and David S. Meyer. 1999. "Missed opportunities: social movement abeyance and public policy." Social Problems 46(2), 187-206.

Scott, James. C. 1990. Arts of Resistance: The hidden Transcript of Subordinate Groups. New Heaven: Yale University Press.

Sewell Jr, William H. 2001. "Space in contentious politics.” In Ronald R. Aminzade, Jack A. Goldstone, Doug McAdam, Elizabeth J. Perry et al., Silence and Voice in the Study of Contentious Politics. Cambridge: Cambridge University Press, 51-89.

Sewell Jr, William H. 2005. Logics of History: Social Theory and Social Transformation. Chicago: University of Chicago Press.

Soifer, Hillel D. 2012. "The causal logic of critical junctures.” Comparative Political Studies 45 (12), 1572-1597.

Tarrow, Sidney G. 2011. [1994] Power in Movement: Social Movements and Contentious Politics. Cambridge: Cambridge University Press.

Taylor, Verta. 1989. "Social movement continuity: The Women's Movement in abeyance." American Sociological Review 54(5), 761-775.

Thompson, E.P. 1971. "The moral economy of the English crowd in the eighteenth century." Past and Present 50(1), 76-136.

Tilly, Charles.1978. From Mobilization to Revolution. Reading: Addison-Wesley.

Tilly, Charles. 2008. Contentious Performances. Cambridge: Cambridge University Press.

Ting, Tin-yuet. 2020. "From 'be water' to 'be fire': nascent smart mob and networked protests in Hong Kong." Social Movement Studies 19(3), 362-368.

Veg, Sebastian. 2017. "The rise of "localism" and civic identity in post-handover Hong Kong: Questioning the Chinese nation-state." The China Quarterly 230, 323-347.

Yuen, Samson and Brian Leung. 2020. "Networked countermobilization: united front and pro-Beijing grassroots organizations in post-handover Hong Kong." Journal of Contemporary Asia.

Yuen, Samson and Edmund W. Cheng. 2017. "Neither repression nor concession? A regime's attrition against mass protests." Political Studies. 65(3),611-630. 
Figure 1. Group Distribution of the Initiation Petitions

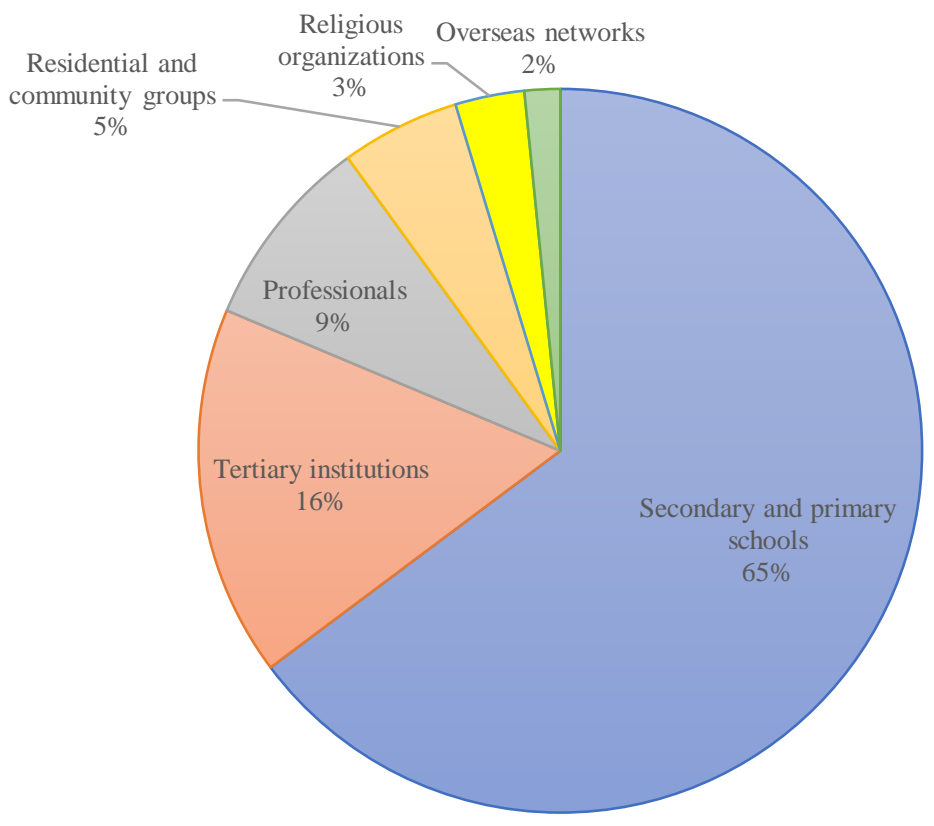

Source: Authors' scraping of 478 online petitions and 269,380 signatories from April to June 2019.

Table 1. Protesters' Involvement in Past Participation and Initial Petitions

\begin{tabular}{|c|c|c|c|c|c|c|c|c|c|c|c|c|}
\hline \multicolumn{13}{|c|}{ Have you signed the following petitions? } \\
\hline \multirow[b]{2}{*}{$\%$} & \multicolumn{3}{|c|}{$\begin{array}{c}\text { Anti-National Education } \\
\text { (2012) }\end{array}$} & \multicolumn{3}{|c|}{$\begin{array}{c}\text { Umbrella Movement } \\
\text { (2014) }\end{array}$} & \multicolumn{3}{|c|}{$\begin{array}{l}\text { July } 1 \text { Rally } \\
\text { (2003-2018) }\end{array}$} & \multicolumn{3}{|c|}{$\begin{array}{l}\text { June } 4 \text { Vigil } \\
(1990-2019)\end{array}$} \\
\hline & Yes & No & $\mathbf{X}^{2}$ & Yes & No & $\mathbf{X}^{2}$ & Yes & No & $\mathbf{X}^{2}$ & Yes & No & $\mathbf{X}^{2}$ \\
\hline $\begin{array}{l}\text { Your school } \\
\text { or alma mater }\end{array}$ & 48.2 & 39.5 & $\begin{array}{c}4.725 \\
*\end{array}$ & 46.6 & 41.4 & 0.012 & 39.1 & 42.1 & 0.447 & 48.9 & 39.8 & $\begin{array}{c}4.703 \\
*\end{array}$ \\
\hline $\begin{array}{l}\text { Your college } \\
\text { or alma mater }\end{array}$ & 39.6 & 26.6 & $\begin{array}{c}11.908 \\
* * *\end{array}$ & 78.0 & 25.1 & $\begin{array}{c}10.285 \\
* *\end{array}$ & 39.6 & 27.4 & $\begin{array}{c}8.980 \\
* *\end{array}$ & 41.9 & 26.7 & $\begin{array}{c}14.916 \\
* *\end{array}$ \\
\hline $\begin{array}{l}\text { Your sector } \\
\text { or industry }\end{array}$ & 25.3 & 21.8 & 1.000 & 75.2 & 19.5 & $\begin{array}{c}5.928 \\
* * *\end{array}$ & 33.6 & 20.5 & $\begin{array}{c}11.911 \\
* * *\end{array}$ & 31.9 & 20.7 & $\begin{array}{c}9.456 \\
* * *\end{array}$ \\
\hline $\begin{array}{l}\text { Other group } \\
\text { or association }\end{array}$ & 55.1 & 47.9 & 3.137 & 79.9 & 47 & 2.246 & 51.6 & 49 & 0.334 & 52.3 & 48.9 & 0.646 \\
\hline
\end{tabular}

Source: Authors' onsite survey on 16 June 2019 with a sample size of 876 . Entries in the Yes and No columns are percentages of respondents who signed these petitions according to their participation in a specific protest movement. Respondents could choose multiple petitions, so the total percentage in each column can be larger than 100 . The $\mathrm{X}^{2}$ values were derived from cross-tabulating the participation in the four protest movements in agreement with the statements. * $\mathrm{p}<0.05 ; * * \mathrm{p}<0.01 ; * * \mathrm{p}<0.001$. 
Table 2. Protesters' Primary Concerns regarding the Extradition Bill

How worried are you regarding the occurrence of the following if the extradition bill is passed?

\begin{tabular}{|c|c|c|c|c|c|c|}
\hline Date & \multicolumn{3}{|c|}{9 June } & \multicolumn{3}{|c|}{16 June } \\
\hline \multirow[t]{2}{*}{ Number } & \multicolumn{3}{|c|}{285} & \multicolumn{3}{|c|}{875} \\
\hline & $\%$ & Mean & SD & $\%$ & Mean & SD \\
\hline Property price drops significantly & 34.3 & 2.94 & 1.338 & 46.6 & 3.39 & 1.212 \\
\hline Foreign capital leaves Hong Kong & 76.2 & 4.00 & 1.113 & 78.0 & 4.14 & 1.014 \\
\hline International community imposes sanctions & 75.0 & 3.99 & 1.061 & 75.2 & 4.07 & 1.021 \\
\hline Extradition of you, your family or friends & 56.2 & 4.02 & 1.103 & 79.9 & 4.26 & 1.039 \\
\hline Extradition of pro-democracy activists and politicians to mainland China & 90.1 & 3.52 & 1.420 & 95.6 & 4.71 & 0.636 \\
\hline Extradition of general public critical of political affairs to mainland China & 90.7 & 4.48 & 0.862 & 95.9 & 4.75 & 0.613 \\
\hline \multicolumn{7}{|l|}{ To what extent do you agree or disagree with the following? } \\
\hline & $\%$ & Mean & SD & $\%$ & Mean & SD \\
\hline Extradition bill turning Hong Kong into One Country, One System & 97.6 & 4.72 & 0.605 & 93.4 & 4.57 & 0.738 \\
\hline Extradition bill destroying the rule of law in Hong Kong & 96.8 & 4.76 & 0.537 & 96.7 & 4.72 & 0.581 \\
\hline
\end{tabular}

Source: Authors' onsite surveys. Respondents were asked to rank their preference on a 5-point Linkert scale. Percentage refers to and combines the extremely worried and worried responses.

Figure 2. Trends of Protests and Protesters, 2019-2020

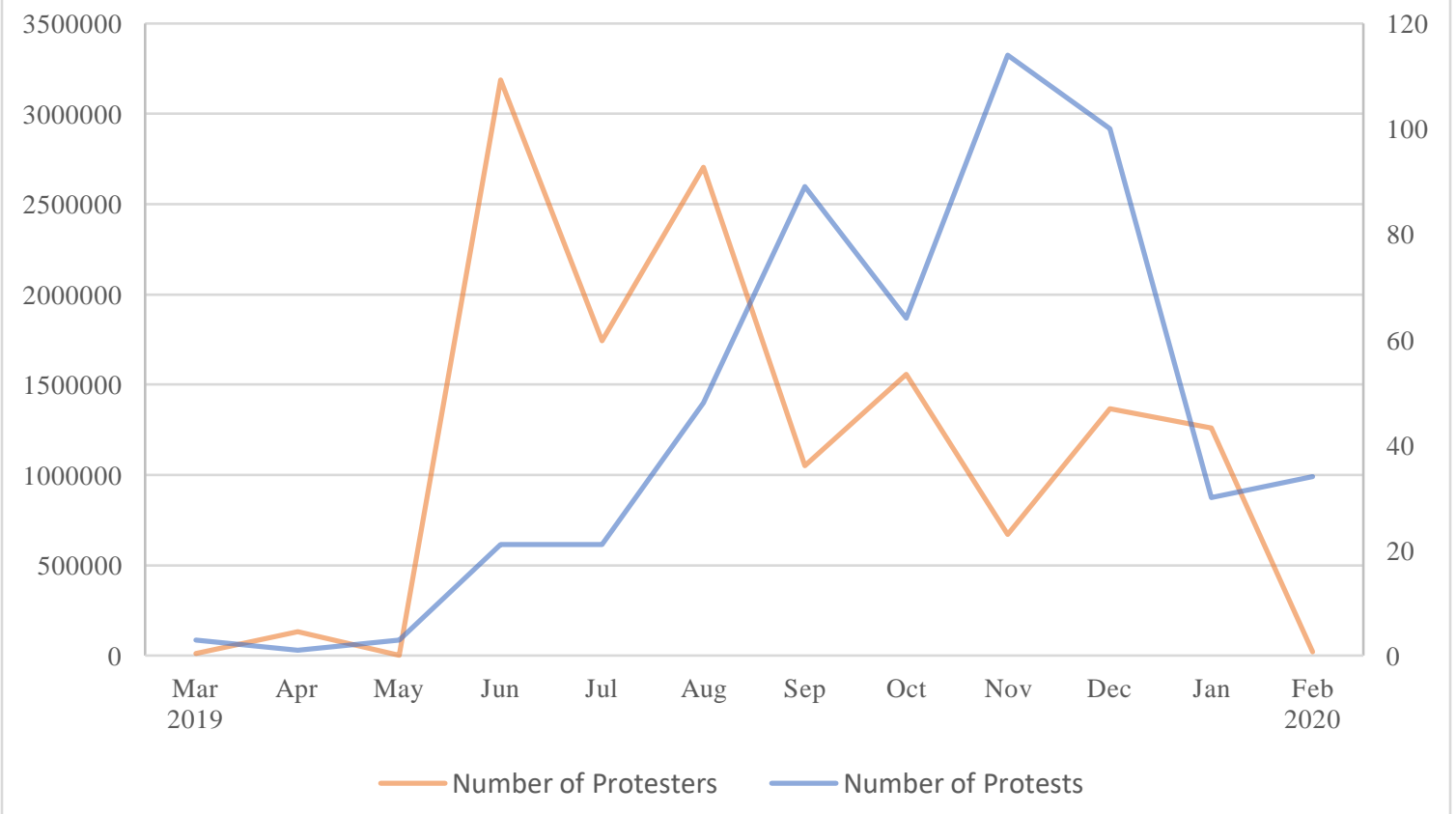

Source: Kong's estimates (2020) with authors' verification and recalculation of 528 protests. 
Table 3. Protest Repertoire

\begin{tabular}{lcc}
\hline Date & 20 Oct & 8 Dec \\
\hline Number & 921 & 902 \\
\hline High-risk activism & & \\
\hline Stop police advance & 6.5 & 13.5 \\
Perform flash-mob & 17.5 & 33.9 \\
\hline Low-risk activism & 57.8 & 61.3 \\
\hline Join human chain & 56.6 & 60.7 \\
Post on Lennon Wall & & \\
\hline Resource mobilization & 44.2 & 44.5 \\
\hline Monetary donation & 41 & 47.3 \\
Material donation & & \\
\hline Online mobilization & 78.4 & 75.4 \\
\hline Share protest information & 86.3 & 79.1 \\
\hline Sign online petition & & \\
\hline Political consumerism & 81.3 & 98.8 \\
\hline Buycott pro-movement business & 88.5 & 98.5 \\
Boycott pro-regime business &
\end{tabular}

Source: Authors' onsite surveys. Entries are the percentage of respondents who did participate in that action. The two protests were large rallies with participants from across the territory, thus illustrating a representative pattern.

Table 4. Political Consumption and Online Mobilization Across Age Groups

\begin{tabular}{|c|c|c|c|c|c|c|c|c|}
\hline Date & \multicolumn{4}{|c|}{$20 \mathrm{Oct}$} & \multicolumn{4}{|c|}{$8 \mathrm{Dec}$} \\
\hline Number & \multicolumn{4}{|c|}{921} & \multicolumn{4}{|c|}{902} \\
\hline Age group & $<25$ & $26-45$ & $>45$ & & $<25$ & $26-45$ & $>45$ & \\
\hline Political consumerism & & & & $\mathbf{X}^{2}$ & & & & $\mathbf{X}^{2}$ \\
\hline Buycotting pro-movement business & 85.3 & 86.1 & 65.2 & $44.226 * * *$ & 99.0 & 98.6 & 97.9 & 1.002 \\
\hline Boycotting pro-regime business & 91.4 & 90.3 & 80.6 & $15.91 * * *$ & 98.7 & 98.6 & 97.1 & 1.805 \\
\hline \multicolumn{9}{|l|}{ Online mobilization } \\
\hline Share pro-movement information & 82.0 & 82.4 & 64.7 & $28.576^{* * * *}$ & 78.9 & 78.7 & 56.6 & $31.745 * * *$ \\
\hline Sign online petition & 84.6 & 89.6 & 81.1 & $9.581 * *$ & 81.5 & 82.3 & 64.3 & $22.364 * * *$ \\
\hline
\end{tabular}

Source: Authors' onsite surveys. Entries are the percentage of respondents who did participate in that action by age group. The $\mathrm{X}^{2}$ values were derived by cross-tabulating the age group and action repertoire in the two protests. $* \mathrm{p}<0.05 ; * * \mathrm{p}<0.01 ; * * * \mathrm{p}<0.001$. 
Figure 3. Scale of Community and Sectoral Mobilizations

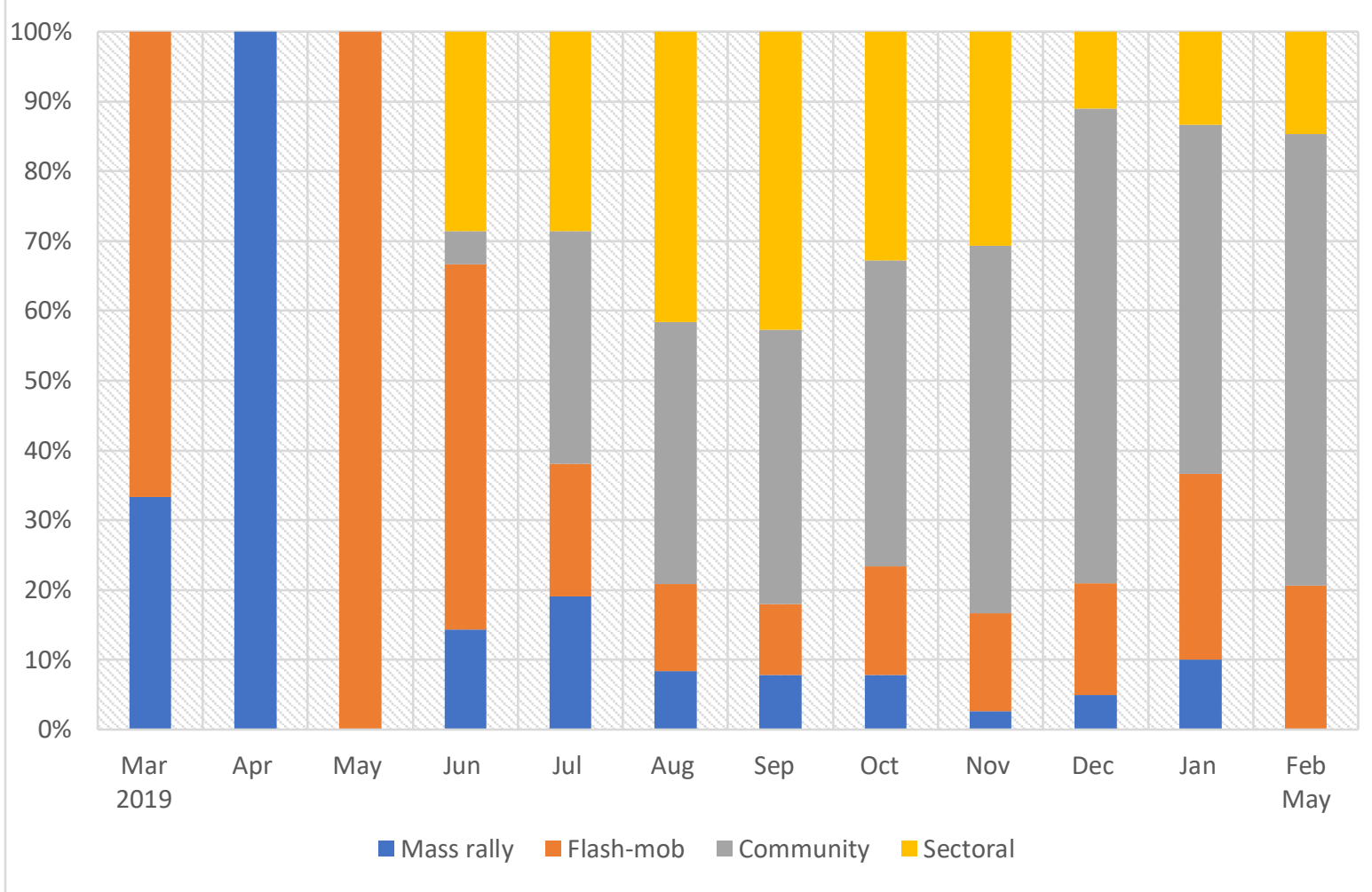

Source: Authors' calculation.

Figure 4. Ranking of Identities on the LIHKG Forum

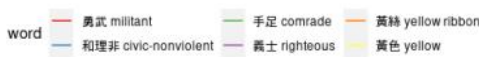

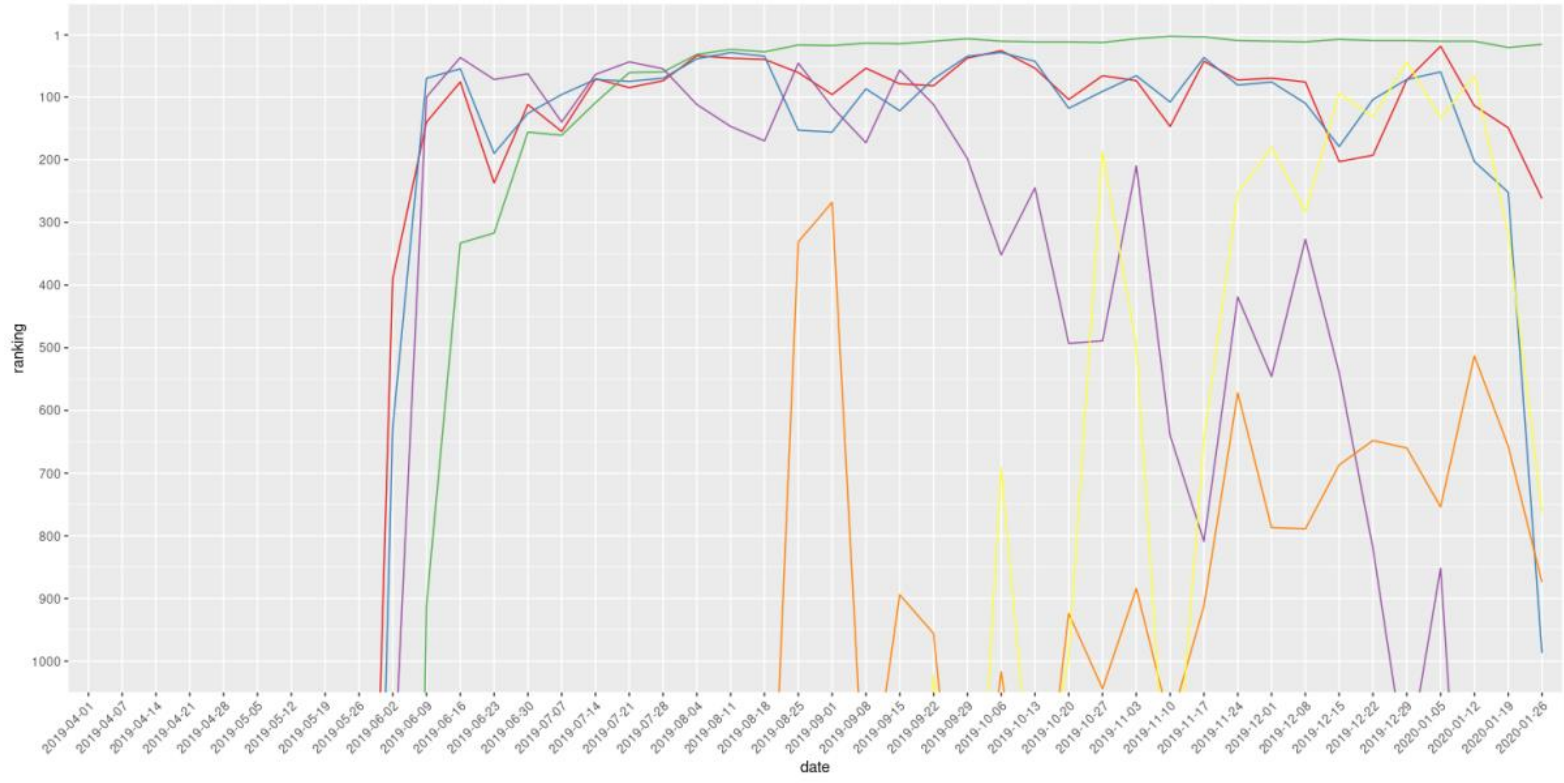


Table 5. Protesters' Emotions across Groups

Which of the following adjectives describes how you felt in the last week?

\begin{tabular}{|c|c|c|c|c|c|c|}
\hline & Fear & Anger & Hope & Anxiety & Worry & Sadness \\
\hline Overall & 24 & 80.5 & 10.1 & 27.7 & 60 & 47.7 \\
\hline \multicolumn{7}{|l|}{ Gender } \\
\hline Male & 18.7 & 80.8 & 11.9 & 27.7 & 56.5 & 46.5 \\
\hline Female & 32.3 & 80.3 & 7.2 & 27.5 & 65.4 & 49.6 \\
\hline $\mathbf{X}^{2}$ & $16.393 * * *$ & 0.004 & 3.67 & 0.000 & $5.188^{*}$ & 0.574 \\
\hline \multicolumn{7}{|l|}{ Age } \\
\hline 25 or below & 27.9 & 83.3 & 11.8 & 29.5 & 63.3 & 42.3 \\
\hline 26 to 45 & 24.9 & 81.6 & 8.2 & 24.8 & 54.1 & 55.8 \\
\hline 46 or above & 11 & 70.3 & 10.9 & 29.7 & 66.1 & 41.5 \\
\hline $\mathbf{X}^{2}$ & 13.582\# & $9.492 * *$ & 2.261 & 1.935 & $7.485^{*}$ & 13.073\# \\
\hline \multicolumn{7}{|l|}{ Class } \\
\hline Middle & 23.5 & 80.4 & 10.9 & 25.3 & 61.2 & 44.4 \\
\hline Lower & 25.1 & 79.1 & 8.6 & 31.1 & 58.1 & 52.2 \\
\hline $\mathbf{X}^{2}$ & 0.138 & 0.087 & 0.652 & 2.342 & 0.543 & 3.55 \\
\hline \multicolumn{7}{|l|}{ Education } \\
\hline Non-degree & 18.2 & 71.5 & 7.3 & 29.9 & 72.7 & 47.3 \\
\hline Degree & 25.8 & 83.3 & 10.9 & 27 & 56.2 & 47.8 \\
\hline$X^{2}$ & $3.644 *$ & $10.537 \#$ & 1.473 & 0.376 & $13.796 * * *$ & 0.001 \\
\hline
\end{tabular}

Source: Authors' onsite survey on 4 Aug 2020 with a sample size of 717. Entries are the percentage of respondents reporting experiencing that feeling about recent events. The $\mathrm{X}^{2}$ values were derived by cross tabulating the age group and gender with protesters' emotions during the protest. $* \mathrm{p}<0.05 ; * * \mathrm{p}<0.01 ; * * * \mathrm{p}<$ $0.001 ; \# \mathrm{p}=0.001$

Table 6. Protesters' Sense of Guilt and Solidarity

To what extent do you agree the following statements regarding militant protesters in the past few months?

\begin{tabular}{lccc}
\hline & $\%$ & Mean & SD \\
\hline Peaceful protesters owe them & 79.5 & 4.28 & 0.956 \\
\hline They make me feel like I'm not contributing enough & 85 & 4.37 & 0.876 \\
\hline I feel guilty when I see them being arrested & 91.9 & 4.59 & 0.683 \\
\hline
\end{tabular}

Source: Authors' onsite survey on 8 December 2019 with a sample size of 902 . Respondents were asked to report their response on a 5-point Likert scale. Percentage refers to and combines strongly agree and agree responses. 